\title{
Breeding biology of coppersmith barbet, Megalaima haemacephala (Müller, 1776)
}

\author{
Noor Jahan Sarker ${ }^{1}$, M. Firoj Jaman ${ }^{1}$, Shariar Mustafa ${ }^{1}$ and Md. Saidur Rahman ${ }^{1}$ \\ Department of Zoology, University of Dhaka, Dhaka 1000, Bangladesh \\ Email: mfjaman@yahoo.com
}

\begin{abstract}
Breeding biology of the Coppersmith barbet, Megalaima haemacephala (Müller, 1776) was carried out between February, 2006 and January, 2007 at Sharawardy Uddyan, Ramna Park, Curzon Hall and National Botanical Garden. The breeding season started from December and ended in June. In total 20 nests were observed, of which 10 nests were studied in details in four study areas. The coppersmith barbet mostly preferred to make holes on the branches of koroi (Albizzia procera) for nesting. Egg laying started on $15^{\text {th }}$ February in the study areas. Average height of nests from the ground was $9.7 \mathrm{~m}$ and average depth and diameter of the holes was $29.20 \mathrm{~cm}$ and $4.46 \mathrm{~cm}$ respectively. New holes were constructed yearly or the old one was reused. Both the sexes took part in incubation of eggs, brooding and feeding to the nestlings. A total of 30 eggs were laid in 10 nests. Clutch size varied from $2-4$ eggs (average: 3 eggs). Among them, 20 $(66.67 \%)$ eggs were hatched and the rest 10 (33.33\%) were unhatched and lost. Average incubation period was 14 days. The male and the female incubated the eggs for an average of 27.44 minutes/ hours and 32.56 minutes/ hours, respectively. Average number of nestlings (brood size) per nest was 2 . Out of 20 nestlings, 16 left their nests successively. The breeding success was $53.33 \%$ in relation to the number of eggs laid and $80 \%$ in relation to nestlings hatched. The average weight of eggs and nestlings was $3.59 \mathrm{~g}$ and $9.33 \mathrm{~g}$, respectively. The main causes of loss of the eggs and nestlings were human interference, predation and ectoparasitic infections. Insects and fruits were fed to the nestlings by their parents.
\end{abstract}

Keywords: Ecology, breeding, nesting, frugivore, Coppersmith barbet.

\section{Introduction}

The coppersmith barbet, Megalaima haemacephala is locally known as 'Choto Basantha Bauri' (Piciformes: Megalaimidae). A total of 80 species of barbets belonged to 11 genera occurs throughout the world, of which 4 species recorded in Bangladesh (IUCN, 2000). It is usually seen alone, in pairs or sometimes in mixed feeding parties, foraging in fruiting trees, especially banyan, peepul and other wild fig trees. Barbets chiefly feed on figs, drupes and berries and sometimes prey moths and flying termites. The coppersmith barbet is common and widely distributed all over Bangladesh. This species occurs in India, Pakistan, Nepal, Bhutan, and SriLanka from the plains and foothills up to $2000 \mathrm{~m}$ (Ali \& Ripley, 1970; Fletcher \& Inglis, 1936; Smythies, 1953; Whistler, 1963). The bird is resident of Bangladesh (Hussain, 1979) and distributed across the country (Khan, 1987; Sarker \& Sarker, 1988). Some works have been done on the distribution, ecology and breeding biology of other species of birds (Ali \& Ripley, 1983; Harvey, 1990; Jaman et al., 1997; Jaman \& Sahreen, 2004; Marshall, 1877; Ray, 1992; Sarker, 1987; Zacharias \& Gaston, 1982).

So far as we know, no any research work on the breeding biology of barbets of Bangladesh was done. This bird helps in dispersal of seeds and act as an ecological indicator of the habitat. Therefore, a detail research on the breeding biology of Coppersmith barbet was conducted. This study may help in the conservation of this important frugivore bird.
Materials and Methods

The study was carried out from February 2006 to January 2007. In total 10 nests were studied in order to collect data on the breeding behavior of coppersmith barbet. The nesting sites were visited on alternate morning and afternoon during the study period. A portable hide was used for closer observation of nest making, incubation activities, feeding of nestling by parents and fledging activities of young birds. Chopper (a butcher's knife having a large square blade) was used in finding the nest of coppersmith barbet, because they made some nests in deep hole. Each nest was marked by marker pen. Wooden ladder was used for climbing the nesting trees in order to measure nests, eggs and nestlings. Height of the nest from the ground and nesting territories were measured by $100 \mathrm{~m}$ plastic tape. Behavioral activities (construction of nest, feeding, preening, gasping, scratching, stretching, roosting, puffing, shaking, etc.) of barbets were observed with the help of a pair of binocular and camera. Spring balance, polythene bags and ropes were used to weigh nests, eggs and nestlings. Watch was used for determining the time for incubating and nonincubating time and feeding visit. Measurement of holes, nestling and young were taken by scale, fine tipped divider, steel tape and slide calipers. The eggs were marked as $1,2,3$, 4, etc. by Chinese ink to determine the incubation period and hatching intervals. The eggs were laid at early morning and the marking on eggs was done on 
the following morning. Nestlings were also marked after hatching with different coloured rubber band. The measurement and weights were taken daily at a fixed time and the records were kept in tabular form with dates. Factors affecting in the damage of eggs and nestlings were also recorded. Mist nets and gloves were used to catch the nestlings and young birds. Activities of young birds before and after leaving the nest were also recorded.

Study area: The study area was at Sharawardy Uddyan, Ramna Park, Curzon Hall and National Botanical Garden. The Dhaka district lies between $24^{\circ} \mathrm{W}$ latitude and $90^{\circ} \mathrm{E}$ longitudes. It is situated at a height of about $7.62 \mathrm{~m}$ above the sea level. Sharawardy Uddyan: This park acquires an area of about 65 acres. There are more than 64 species of plants in the park. Ramna Park: This park is situated in the heart of Dhaka city. It is about 85 acres. Curzon Hall: Curzon Hall is situated at the south-eastern side of the Dhaka University campus. It is about 60 acres and there is a big pond in the middle of this study site. National Botanical Garden: NBG situated at the east side of Mirpur Zoo and $20 \mathrm{~km}$ away from the central point of Dhaka. This garden is about 208 acres. There are 28200 trees under 255 species and 8400 bushy trees under 310 species present.

\section{Results and Discussion}

Breeding season: The first breeding activities of coppersmith barbet (Megalaima haemacephala) was observed to start from early December and continued until last June. The peak breeding time was in March when temperature ranged from $18^{\circ} \mathrm{C}$ - $31^{\circ} \mathrm{C}$, humidity from $70 \%-87 \%$ and average rainfall $49 \mathrm{~mm}$. Ali \& Ripley (1968 - 1974) noted that this bird bred from November to June, peak in February in Indian subcontinent.

Pair formation: We found that pairing of barbet was occurred mainly in December and continued up to mid March. Pair formation is the first step of breeding biology (Welty, 1975). Coppersmith barbet is monogamy bird and formed pair in December when pair was seen closely sat together. Ali \& Ripley (1968 - 1974) noted that barbet formed pair from November to February.

Nest site selection: Both the male and the female selected the nesting site. For making the nest Coppersmith barbet preferred dead or old branches of trees. Ali \& Ripley (1968 - 1974) mentioned that the nest of bird is excavated in a dead or decaying softwood branch. Sometimes, bird left the nesting site after site selection was made. Bird took 7 to 10 days to choose the nest site.
Nesting: It was observed that a pair of Coppersmith barbet made two or three identical holes in the nesting branch, of which only one hole was used for nesting. Rest of the holes could be made for camouflage to protect from predators or enemies. The height of the nest from the ground ranged from $6-13 \mathrm{~m}$ (average: $9.7 \pm 1.59 \mathrm{~m}$ ). We marked 20 nests in 4 species of trees in four study sites. The highest number of nest was $12(60 \%)$ in the branches of koroi (Albizia sp.). The highest number of nests was 7 (35\%) in Ramna park area (Fig. 1). All the nests were more or less similar in size and shape. They made cup shaped nest with the lining of soft grasses and feathers inside the hole, where the eggs were placed. Ali \& Ripley (1983) reported that nest's hole of this bird was long $(25-80 \mathrm{~cm})$ and ending in a slightly widened chamber. It was found that the average length, breadth and depth of nests were $29.20 \pm 2.74 \mathrm{~cm}$, $4.46 \pm 0.55 \mathrm{~cm}$ and $6.31 \pm 0.47 \mathrm{~cm}$, respectively.

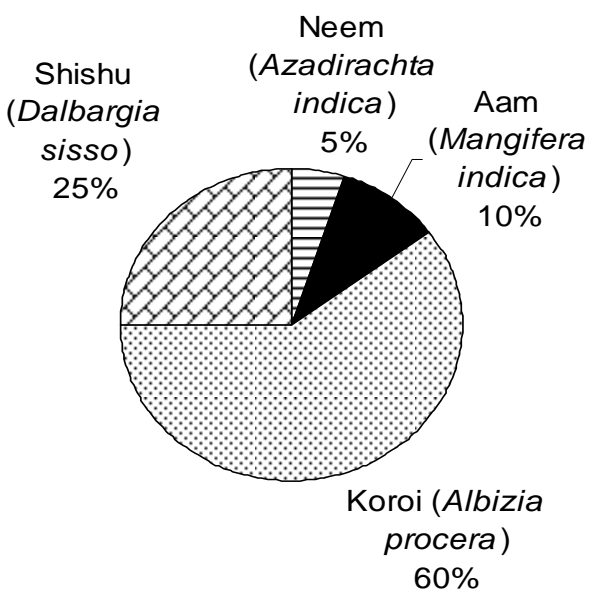

Fig. 1. Percentage of trees used for nesting by Coppersmith barbet.

Territory and habitat: Both sexes of coppersmith barbet were always alert to defend the nest and territory against any other birds which crossed the territory boundary or flew away over the nesting trees. They frequently moved but called not so loudly, because they are very cleaver and exhibit peaceful behavior. They were slightly aggressive during breeding season. If any man who happened to climbed at nesting trees, the birds sat on branches near the nest, and looked here and there very sharply.

Mating: Mating took place on the branches of trees, usually in the morning and late afternoon. Bird mated within few second. Before mating the male and the female sat closely together. At that moment the male scratched the female's forehead for several times. 
Table 1: The measurement of eggs and incubation period of Coppersmith barbet

\begin{tabular}{|c|c|c|c|c|c|c|}
\hline Nest No. & Date of egg laying & Weight(gm) & Length (mm) & Breadth (mm) & Date of hatching & Incubation period (days) \\
\hline \multirow[t]{3}{*}{1} & $8^{\text {th }}$ March & 3.2 & 25.00 & 17.50 & $22^{\text {nd }}$ March & 14 \\
\hline & $9^{\text {th }}$ March & 3.3 & 25.30 & 17.25 & $23^{\text {rd }}$ March & 14 \\
\hline & $10^{\text {th }}$ March & 3.3 & 24.90 & 17.20 & $23^{\text {rd }}$ March & 13 \\
\hline \multirow[t]{3}{*}{2} & $12^{\text {th }}$ March & 3.8 & 25.15 & 17.45 & $26^{\text {th }}$ March & 14 \\
\hline & $13^{\text {th }}$ March & 3.9 & 25.30 & 17.40 & $28^{\text {th }}$ March & 15 \\
\hline & $15^{\text {th }}$ March & 3.8 & 25.25 & 17.20 & & \\
\hline \multirow[t]{4}{*}{3} & $8^{\text {th }}$ March & 3.0 & 25.00 & 17.15 & $23^{\text {rd }}$ March & 15 \\
\hline & $9^{\text {th }}$ March & 3.1 & 25.15 & 17.20 & & \\
\hline & $11^{\text {th }}$ March & 3.2 & 25.50 & 17.45 & $25^{\text {th }}$ March & 14 \\
\hline & $12^{\text {th }}$ March & 3.4 & 25.35 & 17.25 & $25^{\text {th }}$ March & 13 \\
\hline \multirow[t]{3}{*}{4} & $21^{\text {th }}$ March & 4.1 & 24.10 & 16.90 & $5^{\text {th }}$ April & 15 \\
\hline & $22^{\text {th }}$ March & 3.8 & 24.56 & 16.80 & & \\
\hline & $24^{\text {th }}$ March & 4.0 & 24.55 & 16.70 & & \\
\hline \multirow[t]{3}{*}{5} & $14^{\text {th }}$ March & 3.4 & 24.34 & 17.25 & $27^{\text {th }}$ March & 13 \\
\hline & $15^{\text {th }}$ March & 3.7 & 25.14 & 17.30 & & \\
\hline & $16^{\text {th }}$ March & 3.4 & 25.15 & 17.80 & & \\
\hline \multirow[t]{3}{*}{6} & $24^{\text {th }}$ March & 3.4 & 24.67 & 17.65 & & \\
\hline & $25^{\text {th }}$ March & 3.6 & 25.00 & 16.70 & & \\
\hline & $26^{\text {th }}$ March & 3.5 & 24.25 & 17.50 & & \\
\hline \multirow[t]{3}{*}{7} & $11^{\text {th }}$ April & 3.5 & 24.20 & 16.50 & $26^{\text {th }}$ April & 15 \\
\hline & $12^{\text {th }}$ April & 3.3 & 25.50 & 16.50 & & \\
\hline & $13^{\text {th }}$ April & 3.5 & 25.40 & 16.40 & $28^{\text {th }}$ April & 15 \\
\hline \multirow[t]{3}{*}{8} & $14^{\text {th }}$ April & 3.5 & 25.60 & 17.55 & $28^{\text {th }}$ April & 14 \\
\hline & $15^{\text {th }}$ April & 3.4 & 25.45 & 16.50 & $29^{\text {th }}$ April & 14 \\
\hline & $16^{\text {th }}$ April & 3.4 & 25.20 & 16.90 & $30^{\text {th }}$ April & 14 \\
\hline \multirow[t]{3}{*}{9} & $25^{\text {th }}$ April & 3.7 & 24.35 & 16.85 & $8^{\text {th }}$ May & 13 \\
\hline & $26^{\text {th }}$ April & 3.8 & 25.50 & 17.70 & $9^{\text {th }}$ May & 13 \\
\hline & $27^{\text {th }}$ April & 3.6 & 25.30 & 17.55 & $10^{\text {th }}$ May & 13 \\
\hline \multirow[t]{2}{*}{10} & $15^{\text {th }}$ February & 4.1 & 25.25 & 17.50 & $3^{\text {rd }}$ March & 16 \\
\hline & $17^{\text {th }}$ February & 4.2 & - & 17.60 & $5^{\text {th }}$ March & 16 \\
\hline Average & & $3.56 \pm 0.31$ & $24.98 \pm 0.43$ & $17.17 \pm 0.40$ & & $14 \pm 0.99$ \\
\hline
\end{tabular}

Egg laying time and laying sequence: The first date of laying eggs was observed on $15^{\text {th }}$ February and the last on $27^{\text {th }}$ April (Table 1). Egg laying normally started as soon as the nests were completed. Eggs laid regularly one after another and also in successive days with few exceptions having gap of one day. Welty (1975) defined laying as "the deposition of the eggs in the act of position itself and various attendant circumstances". The peak period of egg laying was found in March (Table 1 and Fig. 2). Ali \& Ripley (1970) reported the peak period of egg laying in February.

Clutch size: A total of 10 clutches of eggs were studied. Thomson (1964) defined 'clutch size' as "the complete set of eggs laid by one female which were brooded simultaneously". The clutch size of this species varied from 2 - 4 eggs with an average of 3 eggs. Only one clutch of a pair of birds was recorded in one breeding season.

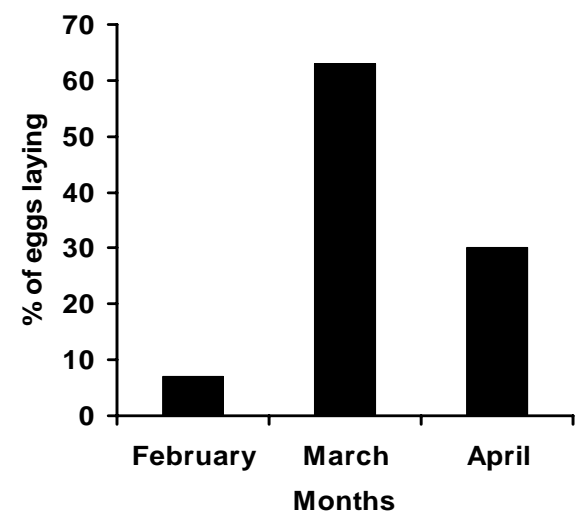

Fig. 2. Egg laying of Coppersmith barbet in successive month.

Measurements and weight of eggs: Eggs were varied in size, colour, dimension and weight even within the same clutch. The length and breadth of 30 eggs were ranged from $24.90 \mathrm{~mm}$ to $25.50 \mathrm{~mm}$ (average: $24.98 \pm 0.43 \mathrm{~mm}$ ) and $17.15 \mathrm{~mm}$ to $17.50 \mathrm{~mm}$ (average: $17.17 \pm 0.40 \mathrm{~mm}$ ), respectively 
(Table 1). The weight of 30 eggs were varied from 3.0 to $4.2 \mathrm{~g}$ (average: $3.56 \pm 0.31 \mathrm{~g}$ ) (Table 1 ). It was found that the weight of the eggs gradually decreased as the incubation continued. But the decreased rate was very high in some eggs, might be due to the infertility of eggs.

Incubation: Incubation started as soon as the first egg was laid and continued up to the hatching of last egg. The incubation period of 20 eggs varied from 13 to 16 days (average: $14 \pm 0.99$ days). The rest of the eggs (10 eggs) were not hatched (Table 1). The incubation behavior was observed in three different nests. In total 36 hours were spent for data collection, of which the male and the female incubated the eggs for an average of 24.44 minutes and 32.56 minutes/hrs, respectively. Out of 20 eggs, $5(25 \%)$ were incubated in 15 days, 7 (35\%) in 14 days, 6 $(30 \%)$ in 13 days and $2(10 \%)$ were incubated in 16 days (Table 1 ).

Loss and infertility of eggs: Out of 30 eggs laid in 10 nests, $10(33.33 \%)$ eggs were lost due to various factors). It was found that some eggs failed to hatch in some nests. It was probably due to the infertility of eggs. The infertile eggs were not removed by the birds from the nest till $5^{\text {th }}$ day after usual incubation period was over.

Loss of nestlings and Nest sanitation: Out of 20 nestlings hatched, we recorded 4 (20\%) nestlings were lost due to human interferences, predation by animals, disease and unknown causes. Barbet was very much careful about their nest sanitation. They always removed any foreign objects, which were harmful for their nestlings. After hatching of each nestling the broken parts of the eggs shell were removed by the parents. Both sexes shared the task of nest sanitation.

Breeding success: Out of 30 eggs, 20 (66.67\%) eggs were hatched and $16(53.33 \%)$ nestlings were successfully grown up and fledged. Therefore, we found $53.33 \%$ of breeding success in relation to eggs laid and $80 \%$ in relation to nestlings hatched.

Dispersal: The young bird left the nests when parents perch on the branch of trees near the nest. After getting food either they returned to the nest or move from one branch to another of the nesting tree. When parents came with the food, the young were called softly (Ki- Ki-Ki......), because they are very gentle bird. At that moment they were jerking their wings and came near the opening of the hole to obtain food from parents. After 2 to 3 days when the young were learned to fly freely then left the nestling tree and never came back. The fledging period (time for young to grow feathers necessary for fly) was about four weeks. Out of 20 nestlings the maximum young fledged in May. Both parents fed the young. After dispersal of the young, they started to lead an independent life.

\section{References}

Ali, S. \& Ripley, S.D. 1968 - 1974. The book of the birds of India and Pakistan.Vols. 1-10, Bombay: Oxford University Press.

Ali, S. \& Ripley, S.D. 1983. A pictorial guide to the birds of Indian Sub-continent. Bombay Nat. Hist. Soc. Bombay, India.

Fletcher, T.B. \& Inglis, C.M. 1936. Birds of An Indian Garden. $2^{\text {nd }}$ edn. 201 pp. Thacker, Spink \& Co. Ltd. Calcutta.

Harvey, W.G. 1990. Birds in Bangladesh, University Press Ltd., Bangladesh.

Hussain, K.Z. 1979. Birds of Bangladesh. Eden Press, Dhaka, Bangladesh.

IUCN. 2000. Red book of threatened bids of Bangladesh. International Union for Conservation of Nature (IUCN), Dhaka, Bangladesh.

Jaman, M.F \& Sahreen, N. 2004. Ecology and breeding Biology of Chestnut - tailed starling, Sturnus malabaricus (Gmelin, 1789). Ecoprint - Int. J. Ecol. 11(1): 27 - 34.

Jaman, M.F., Sarker, S.U. \& Sarker, N.J. 1997. Breeding biology of the black drongo, Dicrurus adsimilis albirictus (Hodgson) in Bangladesh. Dhaka Univ. J. Biol. Sci. 6(2): $185-194$.

Khan, A.R. 1987. Bangladesher Bannaprani, $2^{\text {nd }}$ edn. Bangla Academy press. Dhaka. Vol. 11. Bangla Academy, Dhaka Bangladesh.

Khan, A.R. 1988. Wildlife of Bangladesh. Vol. 11. Bangla Academy, Dhaka Bangladesh.

Marshall, G.F.L. 1877. Birds nesting in India (a calendar of the breeding seasons and a popular guide to the habitats and habits and habitat of birds). Calcutta Central Press. Calcutta. India.

Ray, P.C. 1992. Breeding birds of Ramna Park and Suhrawardy Uddayan. M.Sc. thesis (Unpublished), Department of Zoology, University of Dhaka.

Sarker, S.U. 1987. Breeding records of some birds of Bangladesh. Tiger paper. 14(1): $12-17$.

Sarker, S.U. \& Sarker, S.U. 1988. Wildlife of Bangladesh - A systematic list. The Rico Printers, Dhaka.

Smythies, B.E. 1953. The birds of Burma. $2^{\text {nd }}$ edn. 668 pp. Oliver and Boyd: Edinburg, London.

Welty, J.C. 1975. The life of Birds. WH Sunders Co. Filadelphia.

Whistler, H. 1963. Popular Handbook of Indian Birds $4^{\text {th }}$ edn. Oliver and Boyd: Edinburgh, London.

Zacharias, V.J. \& Gaston, A.J. 1982. Breeding season of birds at Calcutta, South-west India, J. Ibis. 125: 407 - 412. 